\title{
ANALISIS KEBUTUHAN BAHAN AJAR SEJARAH LOKAL DI SEKOLAH MENENGAH ATAS KABUPATEN MADIUN
}

\author{
Sharfina Nur Amalina \\ Universitas Islam Negeri Maulana Malik Ibrahim Malang \\ sharfinaamalina@uin-malang.ac.id
}

Diterima: 06-10-2019.; Direvisi: 26-12-2019; Disetujui: 27-12-2019

Permalink/DOI: 10.18860/jpips.v6i1.7767

\begin{abstract}
Abstrak: Pembelajaran sejarah lokal sangat penting dalam kemajuan pendidikan di Indonesia. Sejarah lokal mampu memberi pemahaman kepada masyarakat mengenai asal ususl sejarahnya, sehingga masyarakat mampu menghadapi realitas masa kini dengan lebih baik. Pembelajaran sejarah lokal perlu dimaksimalkan dalam pendidikan di sekolah salah satunya dengan menambah bahan ajar sejarah lokal itu sendiri. Penelitian ini dilaksanakan dengan tujuan untuk menganalisis penggunaan dan kebutuhan bahan ajar sejarah lokal dalam pembelajaran untuk mendukung literasi budaya sejarah lokal. Penelitian ini menggunakan metode kualitatif dengan pendekatan studi kasus yang melibatkan guru serta peserta didik. Teknik penelitian yang digunakan dengan cara observasi, wawancara, serta mengkaji beberapa dokumen terkait seperti bahan ajar sejarah serta RPP yang digunakan. Pengamatan dilakukan pada dua sekolah menengah atas di Kabupaten Madiun yakni SMAN 1 Mejayan dan SMAN 1 Geger. Hasil penelitian menunjukkan bahwa : (1) bahan ajar sejarah yang digunakan belum mendukung literasi budaya sejarah lokal, (2) siswa membutuhkan materi tambahan sejarah lokal yang memungkinkan mereka melakukan penelitian dan penulisan sejarah yang terintegrasi literasi dengan sejarah lokal.
\end{abstract}

Kata Kunci: literasi, sejarah lokal; madiun; bahan ajar

Abstract: Learning local history is very important in the development of education in Indonesia. Local history is able to understand society about the origin of its history, so that the community is able to better deal with the future. Local history learning needs to be maximized in school education, one of which is by adding local history teaching material itself. This research was conducted with the aim to analyze the use of local history teaching materials in learning to support the literacy of local historical culture. This study uses a qualitative method with a case study approach that involves teachers and students. Research techniques used by observation, interviews, and reviewing several related documents such as historical teaching materials and lesson plans used. Observations were made at two high schools in Madiun Regency, namely SMAN 1 Mejayan and SMAN 1 Geger. The results showed that: (1) historical teaching materials used did not support the literacy of local historical culture, (2) students needed additional local history materials that allowed them to conduct research and improve the history of literacy connected with local history.

Keywords: Literacy, local history; madiun; teaching materials 


\section{PENDAHULUAN}

Pendidikan memiliki peranan yang sangat penting dalam menentukan perkembangan dan terutama bagi perkembangan bangsa. Kemajuan sebuah kebudayaan bergantung pada cara kebudayaan manusia untuk mencari, menghargai dan memanfaatkan sumber daya manusia dan hal tersebut berkaitan erat dengan kualitas pendidikan yang diberikan kepada anggota masyarakat, yakni kepada peserta didik.

Pembelajaran sebagai jantung dari proses pendidikan dalam sebuah institusi pendidikan. Pembelajaran menjadi sangat penting karena dalam proses tersebut terdapat proses interaksi antara guru dengan peserta didik, pembelajaran menjadi wahana informasi dan juga regenerasi budaya dari generasi ke generasi (Susanto, 2014). Arti penting pembelajaran memberikan penjelasan bahwa pembelajaran merupakan proses yang tidak bisa dianggap remeh dalam proses kemajuan suatu bangsa. Pembelajaran sejarah berperan penting, pembelajaran terlihat jelas bukan hanya sebagai proses transfer ide, akan tetapi juga proses pendewasaan peserta didik untuk memahami identitas, jati diri, dan kepribadian bangsa melalui pemahaman terhadap peristiwa sejarah (Susanto, 2014).

Sejarah Nasional Indonesia selanjutnya diturunkan dalam sejarah daerah yang meliputi sejarah berbagai daerah di Indonesia dengan batasan administratif propinsi atau kabupaten. Di luar kedua batasan sejarah sejarah nasional dan daerah, muncul sejarah lokal, yang batasannya ditentukan oleh perjanjian penulis sejarah. Penulis mempunyai kebebasan menentukan batasan penulisannya, apakah dengan skope geografis, etnis, yang luas atau sempit. Sejarah lokal bersifat elastis, bisa berbicara mulai hanya mengenai suatu desa, kecamatan, kabupaten, tempat tinggal suatu etnis, suku bangsa, yang ada dalam satu daerah atau beberapa daerah. Pembelajaran sejarah lokal adalah proses belajar mengajar yang berbasis sejarah lingkungan atau daerah yang dibedakan dengan sejarah nasional. Melalui pembelajaran sejarah lokal siswa akan mengenal bagaimana proses dan perubahan-perubahan yang terjadi di daerahnya. Kalau diartikan sejarah lokal itu semata-mata sebagai sejarah daerah tertentu, maka daerah semacam itu sudah lama berkembang di Indonesia. Bahkan sejarah yang kita miliki sekarang bermula dari tradisi sejarah local.

Pembelajaran sejerah lokal memiliki beberapa tantangan yang dihadapi, meliputi masalah mengenai sumber sejarah, alokasi waktu serta kurangnya inovatif dalam pembelajarannya. Permasalahan mengenai rendahnya literasi sejarah lokal menjadi permasalahan yang harus segera diatasi oleh guru maupun peneliti. Pembelajaran sejarah lokal sebenarnya mampu memberikan peluang bagi peserta didik untuk mendapatkan pengalaman serta informasi sejarah langsung dari tangan pertama sehingga mampu meningkatkan kesadaran sejarah lokal (Kuntowijoyo, 2013). Kesadaran sejarah lokal yang rendah dapat dikarenakan tidak sesuainya penggunaan buku teks dengan kebutuhan, ketersediaan sumber belajar, serta belum ada upaya dari guru maupun sekolah dalam mengintegrasikan sejarah dari suatu daerah ke dalam pelajaran.

Pembelajaran sejarah lokal di SMA dapat dimaksimalkan dengan menggunakan bahan ajar. Bahan ajar sejarah lokal sebagai arahan sekaligus menjadi pedoman dalam proses pembelajaran sejarah lokal. Bahan ajar merupakan faktor eksternal peserta didik yang mampu memperkuat motivasi internal siswa untuk belajar. Lembaga pendidikan Indonesia telah merekomendasikan buku teks sebagai pegangan termasuk buku teks, modul serta lembar kerja siswa dalam setiap mata pelajaran (Krismawati et al., 2018). Pembelajaran dengan menggunakan buku teks pelajaran merupakan dua hal yang 
saling melengkapi (Suyarman, 2006). Pembelajaran akan berlangsung dengan efektif apabila dilengkapi dengan media pembelajaran, yakni berupa buku teks. Buku teks pelajaran dapat disusun serta digunakan dengan baik apabila memperhatikan prinsipprinsip dalam pembelajaran. Dengan demikian buku teks mengenai pembelajaran sejarah lokal yang sesuai dengan prinsip pembelajaran dapat digunakan sebagai sumber pembelajaran dalam pembelajaran sejarah. Dengan latar belakang tersebut maka dalam penelitian ini terdapat rumusan masalah yaitu : (1) bagaimana bahan ajar sejarah lokal yang selama ini digunakan dalam pembelajaran di SMAN 1 Mejaran dan SMAN 1 Geger, (2) bagaimana kebutuhan bahan ajar sejarah lokal untuk meningkatkan literasi sejarah di SMAN 1 Mejaran dan SMAN 1 Geger.

\section{METODE}

Metode yang digunakan dalam pejnelitian ini adalah metode kualitatif deskriptif, yaitu penelitian yang menghasilkan data deskriptif berupa kata-kata tertulis maupun lisan dari perilaku yang diamati. Penelitian kualitatif adalah penelelitian yang bermaksud untuk memahami fenomena tentang apa yang dialami oleh subjek penelitian misalnya mengenai perilaku, persepsi, motivasi, tindakan yang secara holistik, dan dengan cara deskripsi dalam bentuk kata-kata dan bahasa, pada suatu konteks khusus yang alamiah dan dengan memanfaatkan metode alamiah (Moleong, 2013).Dengan menggunakan metode kualitatif penelitian ini dapat dideskripsikan dan diuraikan dengan apa adanya karena penerapan prinsip kualitatif.

Penelitian ini telah dilakukan pada bulan November 2017 sampai bulan Januari 2018. Penelitian dilakukan pada dua SMA di Madiun, yakni SMA Negeri 1 Mejayan dan SMA Negeri 1 Geger, Kabupaten Madiun, Provinsi Jawa Timur. Penelitian di kedua sekolah menengah atas tersebut dilakukan pada guru dan peserta didik kelas $\mathrm{X}$ IPS Peminatan. Sumber data yang digunakan selama penelitian ini adalah informan, lokasi penelitian, dan beberapa bahan ajar sejarah lokal yang dapat digunakan dalam pembelajaran misalnya buku yang berjudul Kesenian Dongkrek, Internalisasi Nilai dan Ketahanan Budaya karya Muhammad Hanif . Wawancara kepada pihak sekolah yakni guru sejarah dan peserta didik di masing-masing SMA. Teknik pengumpulan data dilakukan dengan cara wawancara mendalam, serta kajian terhadap dokumen pembelajaran. Kajian dokumen baik itu berupa arsip, dokumen pembelajaran maupun bahan ajar yang digunakan dalam proses pembelajaran sejarah pada kedua sekolah tersebut di Madiun. Validitas data menggunakan triangulasi sumber yang diterangkan dalam bentuk bagan sebagai berikut : 


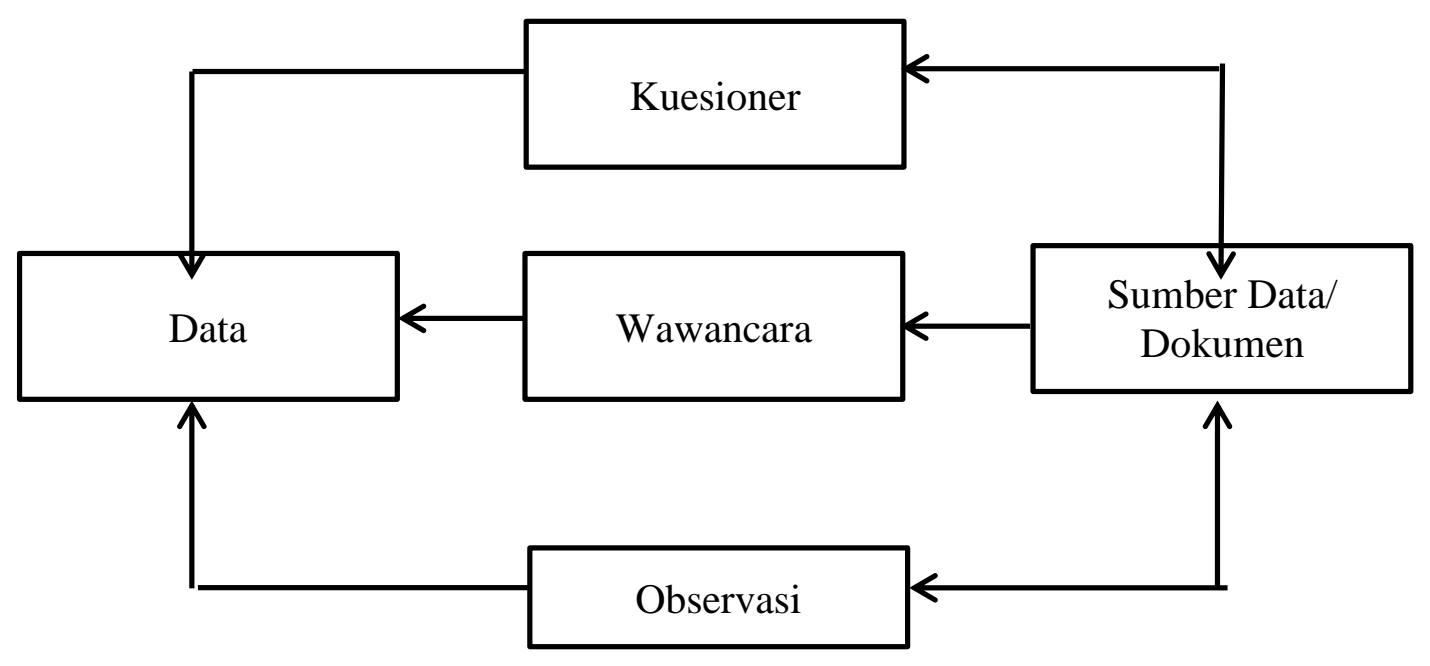

Bagan 1. Metode Triangulasi (Sugiyono, 2015)

Analisis data dalam penelitian kualitatif merupakan upaya yang dilakukan dengan jalan bekerja dengan data, mengorganisasikan data, memilah-milahnya menjadi satuan yang dapat dikelola, mensintesiskannya, mencari dan menemukan pola, menemukan apa yang penting dan apa yang dipelajari, serta memutuskan apa yang dapat diceriterakan kepada oarng lain (Bogdan \& Biklen, 1982). Analisis data dalam penelitian kualitatif dimulai dengan menyiapkan dan mengorganisasikan data berupa teks atau foto yang dianalisis, kemudian mereduksi data tersebut menjadi tema melalui proses pengodean dan peringkasan kode, dan terakhir menyajikan data dalam bentuk pembahasan (Creswell, 2015). Analisis data yang digunakan dalam penelitian ini yakni dengan pengumpulan data, reduksi data, sajian data, dan kesimpulan. Langkah-langkah tersebut dapat digambarkan melalui bagan berikut:

a. Pengumpulan data, menggunakan instrumen yang telah disiapkan guna memperoleh informasi data melalui observasi, wawancara pada guru mata pelajaran sejarah SMAN 1 Geger Madiun dan SMAN 1 Mejayan Madiun di serta dokumentasi. Dalam pengumpulan data ini peneliti melakukan analisis secara langsung sesuai dengan informasi data yang telah diperoleh.

b. Reduksi data dengan cara menyeleksi, memfokuskan, menyederhanakan, mengabstraksikan, dan mentransformasi data mentah yang telah didapatkan dari hasil wawancara dan observasi pada SMAN 1 Geger Madiun dan SMAN 1 Mejayan Madiun. Pada reduksi data ini terdapat analisis yang tajam, ringkas, dan terfokus, sehingga dapat membuang data yang tidak diperlukan.

c. Penyajian data/ pemaparan data merupakan proses merangkai informasi yang telah terorganisir yang mana dapat menggambarkan kesimpulan serta mengambil tindakan selanjutnya.

d. Verifikasi dan menarik kesimpulan, merupakan aktivitas analisis yang mana saat awal pengumpulan data, analisis memutuskan apakah suatu informasi tersebut bermakna, atau tidak mempunyai keteraturan, pola, penjelasan, kemungkinan konfigurasi, hubungan sebab akibat, dan proposisi (Mukhtar, 2013). 


\section{HASIL DAN PEMBAHASAN}

\section{Hasil}

Hasil dari penelitian yang telah dilakukan pada SMAN 1 Geger Madiun dan SMAN 1 Mejayan Madiun menyatakan bahwa pada kedua sekolah tersebut belum adanya sumber bahan ajar sejarah lokal yang digunakan dalam pembelajaran sejarah selama ini. Sejarah lokal Madiun belum pernah diajarkan dalam pembelajaran sejarah, padahal pada kenyataannya Madiun merupakan kota yang terkenal dengan deretan sejarahnya yang dapat dimanfaatkan sebagai bahan ajar sejarah lokal Madiun. Belum adanya bahan ajar sejarah lokal yang dikembangkan dalam pembelajaran sejarah di kedua SMA tersebut berdampak pada budaya literasi siswa yang selama ini masih belum maksimal. Budaya literasi sendiri merupakan hal yang penting bagi siswa sehingga dalam kenyataannya siswa di SMAN 1 Geger dan SMAN 1 Mejayan Madiun sangat membutuhkan adanya pengembangan bahan ajar sejarah lokal khususnya sejarah lokal Madiun dalam pembelajaran sejarah.

\section{Pembahasan}

\section{Bahan Ajar Sejarah Lokal Yang Digunakan di SMAN 1 Mejayan dan SMAN 1 Geger}

Penelitian yang pertama dilakukan di SMAN 1 Mejayan dengan melakukan observasi, wawancara dan penyebaran kuesioner pada siswa-siswi kelas X IPS. Pada SMAN 1 Mejayan dilakukan wawancara dengan beberapa guru sejarah mengenai pembelajaran sejarah selama ini di SMAN 1 Mejayan serta bahan ajar yang digunakan dalam pembelajaran sejarah lokal. Berdasarkan wawnacara yang dilakukan dengan Ibu Sri Handayani Pembelajaran sejarah di SMAN 1 Mejayan saat ini sudah menggunakan inovasi dalam model pembelajarannya, terlebih lagi semenjak diberlakukannya kurikulum 2013. Pembelajaran sejarah khususnya sejarah lokal menjadi lebih terfokus dengan adanya pembagian pada kelompok sejarah peminatan. Model-model pembelajaran yang digunakan dalam pembelajaran sejarah sudah bervariasi,seperti Jigsaw, Pembelajaran Kooperatif, Contextual Teaching and Learning (CTL), Problem Based Learning (PBL) dan lain-lain. Dengan beragamnya model-model pembelajaran yang telah diterapkan di kedua SMA tersebut, integrasi nilai dalam pendidikan sejarah di SMAN 1 Mejayan belum dilaksanakan dengan maksimal (Sri Handayani). Pendidikan nilai saat ini memang penting untuk dimasukkan dalam pendidikan sejarah khususnya pada pembelajaran sejarah sehingga pembelajaran yang berlangsung bisa lebih berkualitas. Hal tersebut juga dibenarkan oleh Bapak Suparyo selaku guru sejarah di SMAN 1 Mejayan,

"Pendidikan nilai dalam sejarah lokal memang perlu dan penting untuk dilaksanakan, terlebih lagi Madiun memang memiliki sejarah lokal Dongkrek yang sudah banyak dikenal" (Suparyo).

Wawancara yang dilakukan bersama dengan para guru yang mengampu mata pelajaran sejarah ditemukan bahwa pembelajaran sejarah yang selama ini berlangsung di SMAN 1 Mejayan telah berjalan sesuai dengan kurikulum 2013. Pembelajaran sejarah yang berlangsung juga telah memiliki inovasi dalam model-model penyampaian materi sejarah. Hal yang perlu diperhatikan lagi adalah bahan ajar sejarah lokal yang belum ada dan belum 
digunakan dalam pengembangan pembelajaran sejarah, khususnya untuk pembelajaran sejarah lokal Madiun itu sendiri. Terlebih lagi dengan Mejayan sebagai daerah mereka sendiri memiliki sejarah lokal yang telah banyak diketahui yakni ritual Dongkrek. Sejarah Dongkrek yang tumbuh dan berkembang di daerah Madiun sebagai sebuah cipta, karsa serta karya masyarakat memiliki kandungan berbagai nilai budaya. Dongkrek sebagai sebuah ritual yang memiliki makna dan fungsi sebagai penolak bala memiliki nilai budaya yang adiluhung. Nilai-nilai budaya Dongkrek yaitu nilai religius, nilai moral, nilai sosial, nilai kepahlawanan, nilai kepemimpinan, nilai estetika dan nilai keadilan (Hanif et al., 2019). Meskipun demikian bahan ajar mengenai materi Dongkrek belum pernah diajarkan dalam pembelajaran sejarah lokal khususnya sejarah lokal Madiun.

Wawancara juga dilakukan pada peserta didik di SMAN 1 Mejayan pada kelas X IPS Peminatan. Pertanyaan yang diberikan adalah mengenai pembelajaran sejarah yang selama ini dilaksanakan dalam pembelajaran serta bahan ajar yang selama ini digunakan dalam pembelajaran. Selain itu, wawancara juga ditujukan untuk mengetahui pemahaman peserta didik tentang sejarah lokal Dongkrek Madiun. Hasil pengamatan menunjukkan bahwa pemahaman peserta didik mengenai sejarah lokalnya masih rendah, hal tersebut berkaitan dengan belum adanya bahan ajar sejarah lokal Madiun yang digunakan. Pemahaman peserta didik mengenai sejarah lokal Dongkrek Madiun sebagain besar masih seputar Dongkrek yang merupakan kesenian khas Madiun. Sejarah dan asal-usul terbentuknya ritual Dongkrek belum dipahami dengan sempurna oleh peserta didik. Hal tersebut tampak pada wawancara yang dilakukan pada salah satu siswi kelas X IPS 1, Mardila Ayu K menyatakan bahwa "Dongkrek merupakan kesenian yang berasal dari Kabupaten Madiun tepatnya di daerah Mejayan". Dyah Erie Shinta juga hanya menjelaskan secara singkat bahwa "Dongkrek adalah sebuah kesenian yang berasal dari Mejayan yang konon pada saat itu terjadi pagebluk yang menyerang masyarakat Mejayan."

Penelitian yang sama juga dilakukan dengan melibatkan guru sejarah dan peserta didik kelas X IPS Peminatan di SMAN 1 Geger. Pembelajaran sejarah di SMAN 1 Geger juga telah banyak menggunakan model-model pembelajaran sepperti halnya di SMAN 1 Mejayan Madiun sebagai inovasi dalam pembelajaran sejarah. Pendidikan nilai juga telah sering digunakan oleh guru sejarah dengan menginternalisasikan nilai dalam pendidikan sejarah. Hal tersebut tampak dalam pernyataan bapak Supriyo dalam wawancara yang dilakukan dengan peneliti. Supriyo menyatakan bahwa

"kurikulum 2013 ini memang sudah pendidikan berbasis nilai yang harus dimasukkan dalam pembelajaran, sehingga dalam proses pembelajaran khsusnya sejarah juga diinternalisasikan nilai-nilai dalam pembelajarannya yang disesuaikan dengan materi yang sedang diajarkannya. Namun, untuk penyampaian nilai sejarah lokal Madiun belum pernah diajarkan terutama karena sejarah lokal Madiun masih terbatas pada bahan ajar di sekolah"

Bahan ajar sejarah yang digunakan di SMAN 1 Geger sebagain besar juga masih mengandalkan buku sebagai sumber utama. Namun, untuk bahan ajar sejarah lokal khususnya sejarah lokal Madiun belum digunakan sehingga dalam prakteknya juga belum pernah diajarkan di dalam pembelajaran sejarah. Dalam wawancara, Supriyo selaku guru sejarah juga menyetujui jika memang pembelajaran sejarah lokal Dongkrek Madiun bisa diajarkan dalam pembelajaran. 
"Sejarah lokal Dongkrek memang memiliki nilai-nilai budaya di dalamnya yang dapat diinternalisasikan dalam pembelajaran sejarah. Sejarah Dongkrek memang belum pernah dimasukkan dalam pembelajaran di kelas, karena terbatasnya bahan ajar di sekolah mengenai sejarah lokal tersebut.",

Hasil dari wawancara terhadap guru dan juga peserta didik menyatakan bahwa pembelajaran sejarah yang selama ini dilaksanakan di SMAN 1 Mejayan dan SMAN 1 Geger Madiun sudah sesuai dengan kurikulum yang saat itu digunakan yakni kuriklum 2013. Pembelajaran sejarah yang telah dilakukan sudah menginternalisasikan pendidikan nilai di dalamnya. Namun dalam perkembanganya sejarah lokal juga nilai budaya lokal belum di ajarkan pada pembelajaran sejarah di kelas khusunya sejarah lokal Madiun itu sendiri. Para guru sejarah di kedua sekolah menengah atas tersebut setuju apabila memang sejarah lokal bisa diintegrasikan dalam pembelajaran sejarah.

\section{Literasi dan Kebutuhan Bahan Ajar Sejarah Lokal Madiun di SMAN 1 Mejayan dan SMAN 1 Geger}

Kurikulum 2013 lebih menekankan pada dimensi pedagogik yang lebih modern dalam pembelajarannya dengan menggunakan pendekatan ilmiah dalam pembelajarannya. Kurikulum 2013 menekankan pada proses pembelajaran saintifik yang menyentuh tiga ranah yaitu sikap, pengetahuan dan ketrampilan peserta didik. Pembelajaran saintifik sendiri merupakan proses pembelajaran yang telah dirancang sedemikian rupa supaya peserta didik secara aktif dapat mengonstruksi konsep, hukum maupun prinsip melalui tahapan-tahapan berupa pengamatan, perumusan masalah, perumusan hipotesis, pengumpulan data, analisis data, menarik kesimpulan serta mengkomunikasikan konsep yang telah ditemukan. Pembelajaran dengan pendekatan saintifik dimaksudkan untuk memberikan pemahaman kepada peserta didik dalam mengenal, memahami berbagai materi menggunakan pendekatan ilmiah, bahwa informasi dapat berasal dari mana saja, kapan saja serta tidak bergantung pada informasi searah dari guru. Kondisi pembelajaran yang diharapkan untuk mendorong peserta didik dalam mencaritahu dari berbagai sumber melalui observasi bukan hanya diberi tahu, (Kemendikbud, 2013, hal 1). Dalam silabus mata pelajaran sejarah peminatan di Kelas X kurikulum 2013 peserta didik dituntut untuk bisa menghidupkan budaya literasi khususnya literasi sejarah. Budaya literasi tercermin dalam beberapa Kompetensi Dasar (KD) dalam silabus mata pelajaran sejarah peminatan di kelas X seperti KD 3.6 yakni Menganalisis berbagai bentuk/jenis sumber Sejarah, KD 4.6 Menyajikan hasil analisis jenis sumber, peran sumber dan keterkaitannya dengan kejadian sejarah dalam berbagai bentuk presentasi, KD 3.7 Menganalisis langkah-langkah penelitian Sejarah terhadap berbagai peristiwa sejarah, dan KD 4.7. Melakukan penelitian sejarah secara sederhana dan menyajikannya dalam bentuk laporan penelitian atau bahkan masuk dalam kompetensi dasar yang lainnya.

Kegiatan literasi sejarah berperan dalam meningkatkan empati peserta didik pada kekayaan sejarah serta budaya yang ada. Kemampuan peserta didik dalam hal membaca dan menulis sejarah termasuk dalam kegiatan literasi sejarah yang sangat diperlukan untuk membangun sikap kritis serta kreatif terhadap fenomena kehidupan. Sedangkan pengertian literasi sejarah lokal merupakan kegiatan literasi yang dilakukan oleh peserta didik untuk menggali sumber-sumber sejarah lokal yang ada disekitar mereka. Sumber-sumber sejarah lokal disini dapat berupa arsip, dokumen sejarah,artefak dan lain sebagainya. Sumber untuk melakukan literasi sejarah lokal di lingkungan sekolah salah satunya yakni dengan bahan ajar sejarah lokal. Sumber bahan ajar sejarah lokal yang tersedia di sekolah saat ini masih 
sangat minim dan belum dikembangkan dengan maksimal. Oleh sebab itulah maka kebutuhan akan bahan ajar sejarah lokal sangat penting guna memaksimalkan budaya literasi sejarah lokal.

Literasi sejarah yang selama ini dilakukan juga masih berfokus pada sejarah nasional. Terbatasnya bahan ajar materi sejarah lokal membuat literasi berdampak terhadap sejarah lokal di sekolah menengah atas. Konteks literasi sejarah lokal khususnya dalam membaca, menulis, dan menciptakan karya ilmiah yang bertemakan sejarah lokal Madiun belum dilakukan di sekolah. Madiun merupakan kota yang mempunyai bermacam-macams sejarah lokal sehingga seharusnya bisa mempermudah peserta didik dalam melaksanakan literasi sejarah lokal. Literasi sejarah dapat dimulai dari ruang lingkup yang lebih kecil serta mengutamakan kedekatan emosional dan intelektual peserta didik yakni melalui literasi sejarah lokal Madiun.

Kegiatan membaca sumber dan menulis sejarah lokal belum menjadi budaya di SMAN 1 Mejayan dan SMAN 1 Geger Madiun sehingga berdampak terhadap kemampuan peserta didik dalam literasi sejarah lokal. Hal tersebut dikarenakan peserta didik lebih terfokus dalam kegiatan membaca buku teks yang menyuguhkan peristiwa nasional. Dapat disimpulkan bahwa rendahnya kemampuan literasi sejarah lokal peserta didik dikarenakan materi sejarah yang didominasi oleh sejarah nasional dan belum adanya penugasan yang mendorong peserta didik ke ranah literasi sejarah lokal.

Hasil wawancara dan observasi yang dilakukan di SMAN 1 Mejayan dan SMAN 1 Geger menunjukkan bahwa buku teks atau bahan ajar sejarah lokal yang selama digunakan belum ada. Hal tersebut juga terlihat pada pernyataan hasil wawancara terhadap peserta didik dan guru sejarah, serta hasil kuesioner yang diisi oleh perserta didik yang menyatakan bahwa pemahaman mereka terhadap sejarah lokal kota Madiun yang masih tergolong rendah. Pembelajaran sejarah yang selama ini dilakukan di kedua sekolah tersebut masih berfokus pada konteks nasional. Oleh sebab itu dipandang perlu untuk mengembangkan sebuah produk yang berupa bahan ajar dengan mengintegrasikan sejarah lokal. Kesadaran sejarah nasional juga dapat dibangkitkan melalui pembelajaran sejarah lokal yang mana juga akan memberikan pemahaman kepada peserta didik tentang nilai-nilai kelokalannya. Sejarah lokal Madiun yang dapat digunakan dan dikembangkan dalam pembelajaran sejarah adalah Sejarah Lokal Dongkrek Madiun serta Situs Ngurawan. Penelitian sejarah lokal oleh Habsari menyatakan bahwa Situs Ngurawan layak untuk dijadikan sebagai sumber belajar sejarah lokal Madiun dengan materi peninggalan sejarah masa kerajaan Hindu. ( Habsari, 2016). Habsari juga menekankan akan pentingnya mempelajari sejarah lokal Madiun dalam pembelajaran di sekolah. Sejarah lokal Madiun mengenai situs kembali ditekankan akan pentingnya sumber tersebut untuk dikembangkan dalam pembelajaran seperti yang ada dalam penelitian oleh Anjar Mukti Wibowo mengenai pengembangan model pembelajaran sejarah lokal di SMA Kota Madiun. Sejarah lokal penting sebagai sumber pembelajaran sejarah karena memungkinkan siswa untuk berhubungan secara sangat "intim" dengan peristiwa yang sangat lokal dan mungkin selama ini dianggap tidak besar, tetapi sesungguhnya memiliki peran penting dan berharga dalam membentuk peristiwa yang lebih besar. (Wibowo, 2016).

Berdasarkan analisis yang dilakukan, peserta didik di SMAN 1 Mejayan dan SMAN 1 Geger membutuhkan bahan ajar yang mengintegrasikan sejarah lokal serta memberikan kesempatan untuk melakukan penelitian dan pencarian sumber. Bahan ajar dengan mengintegrasikan sejarah Dongkrek sebagai studi kasus, maka bahan ajar juga harus disesuaikan dengan prinsip kurikulum 2013. Pada prinsip gerakan literasi sekolah, bahan ajar dibuat dengan memperhatikan beberapa hal : (1) menumbuhkembangkan budaya literasi 
membaca dan menulis peserta didik di sekolah, (2) meningkatkan kapasistas warga dan lingkungan sekolah untuk mendukung budaya literasi, (3) menjaga keberlanjutan kegiatan pembelajaran dengan menghadirkan beragam buku bacaan. Sesuai dengan prinsip 4C, yakni yang pertama communication, dilakukan dengan memberikan kesempatan kepada peserta didik umtuk menyampaikan gagasan terkait materi pada proses pembelajaran, collaborative, melakukan diskusi untuk meningkatkan kemampuan bekerja sama, yang ketiga critical thinking and problem solving dengan memberikan penugasan berupa penelitian dan penulisan sejarah lokal Madiun dengan melakukan proses analisis soisal, terakhir creativuty and innovation dengan mengembangkan dan menyampaikan gagasan melalui penulisan karya ilmiah. Bahan ajar yang didesain harus lengkap sebagai unsur media dan sumber belajar yang memadai sehingga dapat mempengaruhi suasane pembelajaran sejarah lokal yang lebih optimal. Dengan bahan pembelajaran yang didesain secara bagus dan dilengkapi isi dan ilustrasi yang menarik akan menstimulasi siswa untuk memanfaatkan bahan pembelajaran sebagai bahan belajar atau sumber belajar (Astuti, 2016).

\section{KESIMPULAN}

Berdasarkan pembahasan hasil penelitian di yang didapatkan melalui wawancara dan studi dokumen di SMAN 1 Mejayan dan SMAN 1 Geger Madiun dapat disimpulkan beberapa hal yang meliputi 1) Pembelajaran sejarah yang selama ini dlaksanakan di SMAN 1 Mejayan dan SMAN 1 Geger belum memaksimalkan integrasi sejarah lokal beserta nilai-nilai budaya di dalamnya. Buku teks yang digunakan dalam pembelajaran sejarah lokal di SMAN 1 Mejayan dan SMAN 1 Geger Madiun belum mendukung budaya literasi sejarah khususnya bagi literasi sejarah lokal. Sejarah lokal Madiun sendiri belum pernah diajarkan di dalam pembelajaran sejarah di kelas. 2) Pemahaman peserta didik terhadap beberapa sejarah lokal Madiun masih sangat rendah sehingga peserta didik membutuhkan adanya bahan ajar pengayaan yang mampu mengintegrasikan sejarah lokal. Tambahan bahan ajar sejarah lokal tersebut dapat memanfaatkan sejarah lokal Madiun sebagai materinya salah satunya adalah sejarah lokal Dongkrek Madiun serta Situs Ngurawan Madiun. Dongkrek Madiun selain merupakan sejarah lokal yang ada di Madiun sendiri juga didalamnya memiliki nilainilai budaya yang adiluhung sehingga bisa sekaligus menjadi wahana untuk menginternalisasikan pendidikan nilai dalam pembelajaran sejarah. Peserta didik juga membutuhkan kegiatan belajar yang menungkinkan untuk melakukan penelitian serta penulisan sejarah lokal sehingga dapat meningkatkan literasi sejarah lokal. Situs Ngurawan bermanfaat bagi perkembangan pengetahuan peserta didik mengenai sejarh lokal yang merupakan cikal bakal dari bedirinya kota Madiun.

\section{DAFTAR PUSTAKA}

Astuti. (2016). "Pengembangan Bahan Ajar IPS Berbasis Sejarah Lokal". Jurnal Tematik 6 (3). 199-204

Bogdan, Robert C. \& Sari Knopp Biklen. (1982). Qualitative Research for Education : An. Introduction to Theory and Methods, Boston : Allyn and bacon, Inc,

Creswell, John W. (2015). Penelitian Kualitatif \& Desain Riset. Yogyakarta : Pustaka Pelajar. 
Habsari, Novi T. (2016). "Situs Ngurawan: Sejarah dan Potensinya Sebagai Sumber Sejarah Lokal". Jurnal Agastya. Vol. 6 No. 1. Hlm. 58-64.

Hanif, M., Hartanto, Y., Wibowo, A.M., (2019). Kesenian Dongkrek, Internalisasi Nilai dan Ketahanan Budaya. Surabaya : CV. Jakad Publishing.

Krismawati, Warto, \& Suryani. (2018). Kebutuhan Bahan Ajar Sejarah Lokal Di SMA. Cendikia Vol. No. 2, 335-373.

Kuntowijoyo. (2013). Pengantar Ilmu Sejarah. Yogyakarta : PT Tiara Wacana.

Mukhtar. (2013). Metode Prakits Penelitian Deskriptif Kualitatif, Jakarta : Referensi.

Milles, B. Mathew dan Michael Huberman. (1992). Analisis Data Kualitatif Buku Sumber Tentang Metode-Metode Baru. Jakarta : UIP.

Moleong, Lexy J. (2013). Metodologi Penelitian Kualitatif. Bandung : PT. Remaja Rosdakarya.

Sugiono. (2015). Metode Penelitian Kuantitatif, Kualitatif, dan R\&D. Bandung : Alfabeta.

Susanto. (2014). Seputar Pembelajaran Sejarah (Isu, Gagasan dan Strategi Pembelajaran). Banjarmasin : Aswaja Pressindo.

Suyarman, M. dan Utorodewo, V.N. .(2006). Pemilihan dan Pemanfaatan Buku Pelajaran yang Memenuhi Syarat Kelayakan, Jakarta : Pusat Perbukuan Depertemen Pendidikan Nasional.

Wibowo, Anjar M. (2016). "Pengembangan Model Pembelajaran Sejarah Lokal di SMA Kota Madiun”. Jurnal Agastya. Vol. 6 No. 1. Hlm. 46-57. 